\title{
Central Queensland University
}

\section{Leanne Dodd}

\section{Dead men can talk: voicing the dead in crime fiction}

\begin{abstract}
:
Death is frequently the defining event and consequently an indispensable presence, in most crime fiction narratives. Historically, death in crime fiction is embodied in graphic descriptions of the crime scene and the corpse. In an age of significant advances in technology and unlimited access to information, there has been a shift in the sympathies of readers who want to comprehend not only what death looks like, but also what death feels like through the voice of the victim. Traditionally used as a plot device to initiate the detection and investigation of the crime, the corpse has undergone a resurrection that imposes upon the body its own narrative as a means to explore modern social and cultural anxieties surrounding death. Examining the work of crime writers throughout the history of the genre, this paper investigates the representation of death and the dead body's changing purpose within the narrative of crime fiction. Various narrative strategies are identified that inform writers how to engage their intended audience in a conversation with the dead. Considering these in conjunction with trauma theory illuminates how crime writers may assuage some of the cultural taboos and anxieties around death while enhancing the appeal of their crime fiction.
\end{abstract}

\section{Biographical note:}

Leanne Dodd is a doctoral candidate at Central Queensland University, researching the representation of trauma in crime fiction for therapeutic benefit. Under the pen name of Lea Scott, she has published three crime novels with developing themes of trauma and co-authored three short story anthologies with Brisbane writers' groups. Leanne serves as Vice-Chair of the Queensland Writers Centre Management Committee and is an appointed mentor for emerging crime writers. She has appeared on seminar panels and facilitated writing workshops throughout Queensland.

\section{Keywords:}

Creative writing - Crime Fiction - Death Anxiety - Trauma - Corpse 


\section{Introduction}

In his proclamation 'The signature of our species - what separates us from other living, dying beings - is that the dead matter to us' (2006), writer and funeral director Thomas Lynch recognises the existential need for humans to make meaning for the foreboding experience of death. With no credible voice on hand to communicate this experience to them, readers may seek out fictional voices to convey knowledge about death. In crime fiction, characterised as a narrative with 'crime at its core' (Spring and King 2012: 172), death is frequently the defining event that initiates the crime and, consequently, an indispensable presence. Many crime fiction writers thus have the capacity to deliver one of these fictional voices that readers seek.

Writers have multiple motives, but the aim to heighten or alter a reader's sensibilities is at the forefront of most artistic endeavours. Using fiction to help readers structure and order the experience of death to make meaning for their own endings can achieve this aim. In the introduction to their book, Death in Literature, editors Hakola and Kivistö claim that writing about death in fiction can:

provide a narrative closure or even catharsis - an Aristotelian concept which explains how negative events and emotions can be used to serve 'moral' purposes by helping the reader to process negative issues and release emotional tension with a positive solution (2014: x).

Applying these concepts to various forms of crime writing, this article makes a case that voicing the dead in crime fiction has played, and can continue to play, a role in facilitating a reader's ability to control their existential anxieties. It follows that writers of crime fiction can enhance the appeal of their fiction by writing with this motive in mind. While this motive may appear self-serving, there is an admirable link between using beneficial means to a literary end and literary means to a beneficial end. In exploring this approach, writers need to consider how to fit their narrative strategies with their intended audience's needs in a manner that produces outputs that both engage and benefit them.

The socio-historical development of representing death in crime fiction bears relevance in determining how crime writers can appeal to their readers when writing about death. Death in the crime story has served many purposes throughout history, which include educating, cautioning, entertaining, representing trauma and death safely, or voicing the unspeakable. While researchers have closely aligned these purposes to social and cultural attitudes, access to information and the state of technology during the period in which the work was written, this knowledge can also provide insight into audience appeal. This article traces the shifts in the portrayal of death in crime writing by examining the narrative strategies used to give voice to the dead throughout the history of the genre. Two key aims underlie this analysis. The first examines how social and cultural changes have influenced the way writers of crime have voiced the dead. The second uses this socio-historical context to inform modern crime writing practices. Long defined as a unique literary form, crime writers have developed diverse sub-genres, including the 'whodunit', the clue puzzle and the more modern psychological and procedural thrillers (Franks 2011). Rather than aiming for an all-inclusive review, this article will examine specific sub-genres 
that illustrate the wider trends during their reign of popularity in Western culture and look at how they have been able to mediate trauma and alleviate anxieties about death while maintaining audience appeal.

\section{Death as moral instruction and entertainment}

For centuries, writers have employed realism, the attempt to represent art as accurate and true to life, in crime writing. Historically, death in crime fiction was embodied in graphic descriptions of the crime scene and the corpse, the influence for which traces back to Renaissance times. With medicine in a crude state, death was an everyday presence in society, inciting morbid curiosity. The corpse spoke about transgression of the physical boundaries of the corporeal body and instructed society on how to live moral lives within a theological context. Public anatomy demonstrations were staged as entertainment, public executions received widespread attendance (Shillabeer 2014), and dismembered bodies were left on display as an assault on the repose of the soul (Howell 2012: 9). Amidst this culture, an appetite for blood-curdling gothic tales of horror and suspense developed (Franks 2011).

The suspenseful plots of Gothic fiction laid the foundation for more realistic crime fiction to gain popularity in the early eighteenth century. A cheap version, dubbed 'penny-bloods', emerged and created a new readership among the working class for grisly tales of murder (Flanders 2014: 58). By the mid-eighteenth to the earlynineteenth century, readers were flocking to devour real life crime stories being sold in Broadside newssheets and the Newgate Calendar, a bulletin of trials and executions from London's Newgate prison. These publications often followed the progression of a crime over several issues, building their readership as they went (Flanders 2014). While the political aim was to provide lessons against corrupt living (Shillabeer 2014: 103), the criminal was being afforded a voice beyond the grave. Sanctioning the corpse as the object of a voyeuristic gaze cultivated a morbid fascination with the criminal's death. Literary theory defines gaze as the way the writer 'leads the spectator to look in a certain direction or to view things in a certain way' (Murta 2011). While voyeurism denotes visual pleasure, in this sense it describes how these narrative strategies focussed readers' attention on the graphic descriptions of the crime committed and the state of the corpse. A Broadside article titled, 'Horred Murder Committed on the Body of Three Children, by their own father, a man named' [sic], illustrates the gruesome narrative typical of these publications:

one of the children (the girl) fell at her [mother's] feet, with its head nearly cut off, and which he had murdered and thrown after her. The woman opened the door and screamed out, 'that her husband was cutting off their children's heads' (Allen 1807).

This style of crime writing provided readers with a very real space in which to converse with the dead as spectator.

A serialised mutation of the Broadside and the penny-blood evolved, pejoratively termed the 'Penny Dreadful', which profited from this fascination with death by providing the cheap thrill of the fictional crime story in a similar format to that demanded by the blood-lusting audience that had been created, or at least encouraged, 
by the real-life narratives. The well-known character, Sweeney Todd, 'the demon barber of Fleet Street', first appeared in an 18-part Penny Dreadful titled The String of Pearls (The String 1846-7). Its numerous incarnations, most recently in musical stage productions and director Tim Burton's 2007 film, Sweeney Todd: The Demon Barber of Fleet Street, starring Johnny Depp (Zanuck 2007), affirms the appeal of this style of voyeuristic crime narrative.

Later Victorian literature followed a similar tradition to imitate real life despite a growing demand for public morality and decency. Dickens' Oliver Twist credibly portrayed the urban underbelly of London and its criminal inhabitants, with the murder of Nancy by Bill Sikes causing crowds to flock to readings of the death scene (Flanders 2014: 385). Dickens defended his use of realism in the preface to the 1841 edition:

to show them as they really are, for ever skulking uneasily through the dirtiest paths of life, with the great, black, ghastly gallows closing up their prospect, turn them where they may; it appeared to me that to do this, would be to attempt something which was greatly needed, and which would be a service to society (1966: 1xii).

Here and elsewhere in his writing, Dickens demonstrates the potential of crime fiction during the Victorian era to be a significant instrument of education, social critique and control.

By exercising realism in their narratives, early writers of crime fiction represented death as macabre and entertaining, yet this realism also functioned veraciously to provide opportunities for readers to work through their anxieties about death through voices removed from their personal circumstances: 'As Aristotle noted in his Poetics, people are fascinated with scenes of death and in fiction they are content to see things they would prefer to avoid in their own lives' (cited in Hakola and Kivistö 2014: xiv). More recently, Sims, Emeritus Professor of Psychiatry at the University of Leeds, suggests that the more writers describe death and dying in literature as true to life, the more effective the opportunity becomes for readers to relate to them (2003). Awardwinning Australian crime writer, Peter Temple, is known for his tough realism. In his 2005 novel, The Broken Shore, he portrays how his homicide detective, after hearing about the death of three boys, 'felt the sudden withering ache of loss and mortality' (2005: 315), allowing readers to share an empathetic view of these personallyunrelated deaths. This novel's hefty body count also maintains audience engagement by inciting readers' morbid fascination with death. The use of realism remains broadly applicable as a strategy for crime writers seeking voices to support their readers in confronting death on its own terms rather than seeking to understand through private loss, and as a strategy to entice and engage their audiences.

\section{Death as vivification of the corpse}

The popularity of the crime genre continued to rise during the genre's so-called Golden Age, the period between the first and second world wars. In the 1934 Introduction to Great Short Stories of Detection, Mystery and Horror, crime writer Dorothy Sayers wrote: 'Death seems to provide the minds of the Anglo-Saxon race 
with a greater fund of innocent enjoyment than any other single subject' (qtd. in James 2011: 3). The phrase 'innocent enjoyment' seems at odds with the subject matter of death, but needs to be viewed with an awareness that this period marked a significant shift in popular cultural attitudes to death during which the body became hidden and social norms re-fashioned death into a taboo subject. Thornton confirms 'by the early twentieth century, death had become invisible, an embarrassing, even obscene fact to be hidden away' (1997: 433). Crime writers subjected the murdered corpse to a similarly averted gaze in this era.

The comforting 'whodunits' and puzzle mysteries that emerged, with their reassuring generic conventions, permitted readers to escape into even safer fictional worlds to face issues surrounding death. Unlike reality, they guaranteed the restoration of social and moral order through their formulaic nature, and ultimately explained senseless acts and causes of death through reason and punishment (Turner 2003: 4). Death scenes in Golden Age crime novels conveyed a sense of reassurance because they were conventional and impersonal as a rule, with details regarding the actual process of death frequently hidden from the reader.

Agatha Christie's The Murder of Roger Ackroyd (1926) reflects how Golden Age crime fiction commonly disavowed the process of death. Christie narrates the moments before and after the death, but its actual occurrence is absent from the text. Her description of the death scene is brief and clinical, sparing the reader from exposure to any transgression of the physical boundaries of the body. The narrative intention, as Covino posits, appears to 'disavow our excretory bodies because they are signs of disorder, reminders of the body's ambiguous limits ... and of its ultimate death' (2004: 17). Christie even hides the wound caused by the embedded dagger from sight below the collar of the victim's coat.

Ackroyd was sitting as I had left him in the armchair before the fire. His head had fallen sideways, and clearly visible, just below the collar of his coat, was a shining piece of twisted metalwork ... I did what little had to be done. I was careful not to disturb the position of the body, and not to handle the dagger at all. No object was to be attained by moving it. Ackroyd had clearly been dead some little time (2011: 49).

Heddendorf refers to the body in this type of crime fiction as the 'functional corpse' (2014: 120). The functional corpse can be understood in terms of psychoanalyst Kristeva's theory of abjection, which results from 'that which disturbs identity, system, order' (1982: 4). The once human body is no longer human, and therefore abject and incomprehensible to those living (Howell 2012: 10). To negate the abject body, cultural practices of embalming and post-mortem photography became common in some countries during this era, revivifying the corpse by reinforcing the illusion of the dead body as still life-like. Through this process, however, the corpse became 'drained of both blood and meaning' (Thornton 1997: 433). The crime fiction of the period mirrored these social attitudes. The body did not speak for the dead but was relegated to the position of a plot catalyst. Christie's narrative delivers a brief description of the dead body then shifts into professional mode, with the investigation taking over. 
Such writers did grant the dead a voice, but it is the second-hand voice delivered through hearsay and witness testimony that appeals to readers of this style of crime fiction. An investigative gaze is a paramount strategy for writers to follow to convey this voice. Testimonies often revealed a great deal of information about the 'living' victim, allowing the dead to remain animated in readers' minds. Within the highly formulaic conventions of the genre, it was also commonplace for the victim to be a heinous and disliked character. This served to impersonalise the death even more, so that the 'reader feels nothing when they die' (Heddendorf 2014: 118). Christie's 1930 novel, Murder at the Vicarage, pays reverence to the cultural attitudes of its time. The vicar, an authoritative man of God, describes the murder victim in such a way: I remarked, in a spirit most unbecoming to my cloth, that anyone who murdered Colonel Protheroe would be doing the world a large service' (2011: 1) and he reinforces this shortly after with 'a world without Colonel Protheroe in it would be improved for the better' (28).

At a time when religious beliefs were still strong, the dead remained hidden and speaking of death was taboo, this narrative strategy reinforced cultural views by describing the victim only in his or her living state. Lucas claims that death can be 'repressed in order to sustain ourselves as living subjects' (2004: 216) and deny our mortality. Golden Age crime writers revivified the corpse throughout the narrative and maintained a deceptive sense of immortality for their readers.

The recent popularity of crime novels such as Kerry Greenwood's Miss Fisher Murder Mysteries series, adapted by ABC into a television series (Eager and Cox 2012-2015), indicates that there continues to be an audience for comforting 'whodunits' and puzzle mysteries. James asserts that the 'continued popularity and worldwide appeal suggests that in our 21 st century the detective story, old and new, will continue to provide distraction, entertainment and relief in our increasingly complex and disorderly world' (2013). Evidence suggests that writers of historical styles of crime fiction should endeavour to focus their conversations with the dead around these strategies to appeal to audiences who prefer to momentarily keep cultural anxieties surrounding death at bay.

\section{Death as spectacle}

In the twenty-first century, death is no longer a social taboo concealed in whispers behind hands or funeral home doors. While death commonly occurs in medicalised institutions and corpses remain beyond sight, reports of death as spectacle confront modern society in increasingly graphic ways across multimedia platforms (Hakola and Kivistö 2014). Crime writer Val McDermid confirms that 'as a result of 24-hour news, we are more aware than ever before of the atrocities that are happening' (qtd. in Shillabeer 2014: 109). While cultural anxieties surrounding death remain strong, readers no longer predominantly ground these fears in religious concerns or the sociocultural consequences of bad moral choices. In an age of unlimited access to information, fears partly revolve around the risks of living in today's unpredictable world based on exposure to what is being termed a trauma or 'wound culture' (Shillabeer 2014: 104). In addition, significant advances in medical and scientific 
fields produce barrages of information promoting an anti-aging culture, with false promises of immortality, in which the anxiety surrounding death has transgressed toward the pain of dying and the loss of an unfinished life. Allowing readers to face these experiences in the safe environment of the narrative offers a way of empowering them with the knowledge they need to absorb the shock of trauma and death (Whitehead 2004). Contemporary crime fiction writers hold the key to providing a means of exploring some of the implications of their readers' fates - and ways for them to take control - while continuing to be a form of popular entertainment.

Today, the range of crime fiction sub-genres has expanded to include many more categories, including legal and police procedurals, psychological profiling and forensic medicine procedural novels, and psychological and supernatural thrillers. Narrative strategies used to voice the dead in contemporary crime fiction, viewed in conjunction with trauma theory, indicate a shift in the sympathies of these new audiences who want to comprehend not only what death looks like but also what it feels like. Trauma theorists such as Caruth (1996) have established that trauma is not fully assimilated as is occurs, but is experienced as latent and repetitive intrusions of memory. Examination of the narrative strategies used in trauma narratives, defined succinctly by Vickroy as 'fictional narratives that help readers to access traumatic experience' (2002: 1), provides insight into ways that crime writers can represent this fragmented and repetitive nature of traumatic memory to allow readers to witness death and confront their fears within the safe space of the narrative. Whitehead has recognised in her seminal work on trauma literature that 'novelists have frequently found that the impact of trauma can only adequately be represented by mimicking its forms and symptoms' (2004: 3). Two of the main strategies she identifies in trauma narratives to mimic trauma are repetition and fragmentation. By mimicking the effects of trauma caused by death, crime writers can provide readers with a path to understanding and processing the anxieties surrounding death in the twenty-first century.

Repetition is a narrative strategy that crime fiction audiences are familiar with, even if unconsciously. The formulaic model of the crime novel, with its restoration of social and moral order, presents readers with a form of repetition that graphically tells similar kinds of stories exploring death, yet contains them within the form of the genre. This intensifies its appeal to readers as 'a way of incrementally adjusting to what is otherwise unbelievable, beyond comprehension, what cannot possibly be assimilated as it first happens' (Lucas 2010: 207). Narrative repetition mimics the nature of trauma and acts to desensitise readers to experiences of death in the way that a mother may rhythmically rock a child to alleviate distress (Lucas 2010: 207). When allowed to confront the incomprehensible subject matter of death in crime novels repetitively, readers are able to assimilate the nature of trauma and death gradually.

Forensic procedural novels often employ repetition through the medical gaze. Foucault first used the term 'medical gaze' to explain the process of medical diagnosis and the authority of medical knowledge in society (1973). Forensics is grounded in this same paradigm of rationality and medical science. 
The language of science is invoked as an ordering principle, reminding us of the "true nature of things", and reassuring us by providing the "illusion of fullness" and the sense that "enough facts can produce whole knowledge" (Palmer 2001: 58).

Scientific rationality brings with it a sense of authority that Lucas asserts offers a 'template of understanding' (2010: 219) for our frailty and mortality where the 'physical body becomes a site of intense looking and analysing' (217). With an everincreasing demand for detailed information about death, coupled with advances in forensic medicine and computer-generated images, society continues to be desensitised by looking upon the recurring motif of the decomposing and mutilated corpse. Since the first public television autopsy was performed as a form of edutainment by Professor Von Hagens in 2002 (Steenberg 2013), the medical gaze has made death prevalent in the forensic sub-genre, popularised by bestselling crime writers such as Patricia Cornwell and Kathy Reichs. The work of both writers has been successfully adapted for television and Shillabeer suggests this growing visual exposure to death has had a direct effect on the literary genre of crime fiction by blunting our disgust reaction (2014:106). As a result, the usual restrictions of taste do not bind forensic crime novels because writers base their work on the premise that the corpse is the site for gaining knowledge about death through intense visual scrutiny.

In describing the work of Cornwell, Lucas states, 'Blood shocks. Vermillion, spurting, oozing, it immediately marks transgression, the breakdown of what we like to imagine are impermeable boundaries' (2010: 216). Forensic procedural novels demonstrate a capacity to push the boundaries when describing the unspeakable physical elements of death such as bodily excretions and wounds. The clues gleaned from the excavatory forensic examination of the corpse speak for the victim by communicating acts inflicted upon them in the process of death (Lloyd 2014: 104). Forensic pathologists must not only look, but also listen, to what the corpse is telling them to solve the crime. Reichs demonstrates this narrative strategy in her forensic procedural novels. In Spider Bones (Reichs: 2011), the revelations of the victim's corpse become key to the investigation, communicating to the forensic pathologist that the victim had endured being burnt in the process of death:

With a gloved finger, I scraped one cranial fragment. Below the outer crust, the cortical surface was black and flaky. Again, consistent with Johnson's report of body condition. The deceased had suffered a fiery event (60).

Despite the increasingly gruesome nature of this sub-genre of crime fiction, critics argue that these patterns of predictability and repetition, coupled with medical authority, are comforting. Readers can trust in the extremes of exposure to trauma and death because they know from experience the crime novel will carry them securely through to a resolution that restores the world to order (Lucas 2010: 210). By engaging in a strategy that adheres to the formulaic form of repetition, writers of modern procedural crime fiction are able to provide their audience with a safe and intimate knowledge of death denied to them in real life, which can, in turn, be mesmerising for their audience.

Fragmentation is a strategy that writers can achieve by using analepsis, a narrative device also referred to as flashback. Literary theorist Todorov describes how in crime 
narratives 'time is a critical design feature ... leading us slowly backwards from effect to cause' (1977: 47). Crime novels often employ analepsis/flashback to reveal clues about events from the past. This strategy can be used to bestow a voice on the dead by transporting readers to a time when the victim was alive, fundamentally blurring the borders between life and death through the fragmentation of the narrative. Differentiated from the way the dead were voiced through witness testimony that was typical of Golden Age crime fiction, the narrated voice belonging to the contemporary crime fiction victim creates an empathetic connection with readers. Lloyd suggests 'creating a fiction which tries to somehow engage with the dead and to listen to them attempts to make sense of what is totally senseless' (2014: 106). Having a fictional conversation with those who have made this journey assists readers to reflect on the dichotomy between living and non-living, and to make sense of their own personal journey into the land of the dead.

One way writers can exercise analepsis is through posthumous narration, which allows a narration of the 'experience' of death through the voice of the dead narrator. In Alice Sebold's supernatural thriller, The Lovely Bones (2002), the protagonist, Susie, is already dead. Her opening lines look backward as she narrates her rape and murder. 'I was fourteen when I was murdered on December 6, 1973' (5). Sebold juxtaposes this with parts of Susie's everyday life.

In my junior high yearbook I had a quote by a Spanish poet ... I thought it marked me as literary. I was a member of the Chess Club and the Chem Club and burned everything I tried to make in Mrs. Delminico's home ec class (5).

This form of analepsis allows the reader to form an empathetic connection with Susie before she moves on to narrate the traumatic 'experience' of her death. Sebold's only reference to the body in Susie's narration is 'Gilbert's dog found my elbow three days later and brought it home' (10). This account departs from the visceral description of the body encountered in procedural forms of crime fiction, to a more empathetic view of the victim for an audience seeking to understand what death feels like.

Throughout the narrative, Sebold cites a movement between the past and the present through Susie's narration of memories of her former life, her death, and her witness accounts of those she has left behind. The fragmented narrative arc mimics the symptoms of trauma, providing a space for readers to process the traumatic experience of death through Susie's testimony and to contemplate an existence beyond death. After exploring these implications, Sebold brings us to a comforting resolution in which Susie eventually accepts her absence from the living world, and the passage from which the novel's title is taken:

These were the lovely bones that had grown around my absence; the connections, sometimes tenuous, sometimes made at great cost, but often magnificent - that happened after I was gone. And I began to see things in a way that let me hold the world without me in it (320).

This narrative strategy uses analepsis to express to readers that death fits into the overall scheme of life, and as Lynch suggested at the beginning of this article, the dead do matter (2006). Sebold confirms that Susie's life remains intricately woven into the fabric of the universe. Linguist and medical educator, Skelton, suggests that 
stories about death bring with them an illusion that both a reader's life and death will have mattered in this existential scheme (2003: 215). By integrating this strategy into their crime novels, writers support readers to make meanings that enable what Messud terms a 'noble death' that 'consoles us, and assures us that somehow we can remove its sting' (2009: 1), because existence is infinite. Assuming that the target audience for supernatural crime fiction is likely to accept this premise as true, then in this way the crime writer can heighten audience appeal.

A further way writers can exercise analepsis is to convey the voice of the victim through diary entries. Gillian Flynn's crime thriller Gone Girl (2012) incorporates elements of this strategy in Amy's diary entries detailing her life leading up to her disappearance. Her diarised suspicions about her husband's behaviour that implicate him in her alleged death are interspersed amidst the linear present-day story of her disappearance, taking readers back to the past.

\section{AMY ELLIOTT DUNNE}

August 17, 2011

DIARY ENTRY

I know this sounds the stuff of moony teenage girls, but I've been tracking Nick's moods. Toward me. Just to make sure I'm not crazy. I've got a calendar, and I put hearts on any day Nick seems to love me again, and black squares where he doesn't. The past year was all black squares, pretty much (167).

A plot twist eventually reveals that Amy has faked both her disappearance and her diary entries but this, nevertheless, provides a good example of how this narrative device can increase the reader's empathetic connection with the victim by allowing them to tell their stories from beyond the grave. Chalupský suggests the faked diary is in itself an artistic enterprise, exploring the mind, motives and preparations of its writer (2010: 125). This narrative strategy offers writers a further way to explore the life and death experience and in doing so, allow readers to watch and follow to make meanings for their own ultimate ending.

\section{Conclusion}

In his 1846 essay, Edgar Allan Poe argues that 'only with the dénouement constantly in view [can we] give a plot its indispensable air of consequence, or causation' (2003: 430). So too, it may be, that humans can only plan and order their lives with an understanding of the end in view. For this reason, readers of crime fiction may seek out fictional voices to communicate knowledge about death. Fiction touches our emotions and effectively dissolves barriers between the reader and the text, as evidenced in Strubel's reflection:

As a child, I read in order to be consoled about my inability to imagine non-being in its infinitude. Through the act of reading, this experience became something universal. In books, all those doubting, sentient, questioning "I's" had the same questions I had had, and some of them even had answers, and I understood all of them, I felt close to them all, I saw myself in all of them, I identified with them so intensely, it felt as if I had exchanged my life with theirs, or had become one with them, and maybe that was true, 
because I triumphantly believed I had experienced how that which cannot be, could be (2014: 6).

Struble further suggests 'Consolation cannot be found in textbooks. Nonfiction gives us information, but it does not provide us with comfort' (9). Crime fiction, with its formulaic closure and capacity to voice the dead, therefore holds a certain power that addresses these issues of existential concern in a way that other forms of fiction are not able to achieve.

This brief history has provided an overview of the directions writers have taken to voice the dead in crime fiction. However, it becomes clear that the study of writing about death is intimately bound up in the social attitudes not only of the era in which writers generate their fiction, but also the way in which varying social attitudes prevail in modern times for the divergent audiences of crime fiction sub-genres. The corpse, traditionally used as a plot device to moralise or to initiate the investigation of a crime, has more recently undergone a resurrection that imposes upon the body its own narrative to explore modern social and cultural anxieties surrounding death. While audiences have grown for this style of crime fiction, its appeal is not universal, and demand also continues for cosier-styled crime fiction. This diversity highlights the need for writers to employ varying narrative strategies to engage their specific audiences in a conversation with the dead to help readers give shape to their thoughts and feelings around the experience of death. The strength of such an approach is authenticity, both to the conventions of the sub-genre and to alignment with the audience's social attitudes to death. By providing knowledge about death in a way that is comprehensible to their intended audience, writers can strengthen their engagement with their readers and consequently enhance the appeal of their crime fiction.

\section{Works cited}

Allen, G and Great Britain. Assizes (Stafford, England) 1807 Horred murder committed on the body of three children, by their own father, a man named London: Pitts

Caruth, C 1996 Unclaimed experience: Trauma, narrative and history Baltimore: John Hopkins UP

Chalupský, P 2010 'Crime narratives in Peter Ackroyd's historiographic metafictions' European Journal of English Studies 14 (2), 121-131

Christie, A 2011 [1930] The murder at the vicarage New York: Harper Collins

Christie, A 2011 [1926] The murder of Roger Ackroyd New York: Harper Collins

Covino, DC 2004 Amending the abject body: Aesthetic makeovers in medicine and culture Albany: State U of New York P

Dickens, C 1966 [1837-9] Oliver Twist Oxford: Clarendon

Eager, F and D Cox (producers) 2012-15 Miss Fisher's murder mysteries [television series] Australia: Australian Broadcasting Corporation

Flanders, J 2014 The invention of murder: How the Victorians revelled in death and detection and created modern crime New York: St. Martin's

Flynn, G 2012 Gone girl New York: Crown

Foucault, M 1973 The birth of the clinic: An archaeology of medical perception New York: Pantheon 
Franks, R 2001 'May I suggest a murder? An overview of crime fiction for readers' advisory services staff' Australian Library Journal 60 (2), 133-143

Greenwood, K Phryne Fisher, at http://phrynefisher.com/books.html (accessed 4 May 2016)

Hakola, O and S Kivistö 2014 'Introduction: Death in literature' in O Hakola and S Kivistö (eds) Death in literature Newcastle upon Tyne: Cambridge Scholars, vii-xix

Heddendorf, D 2014 'Murder in a clear, cool voice' Southern Review 50 (1), 116-122

Howell, K 2012 'The suspicious figure of the female forensic pathologist investigator in crime fiction' M/C Journal: A Journal of Media and Culture 15(1), at http://journal.mediaculture.org.au/index.php/mcjournal/article/view/454 (accessed 24 April 2015)

James, PD 2011 Talking about detective fiction New York: Vintage Books

James, PD 2013 'P. D. James: Who killed the golden age of crime? Remembering the gentlemanly world of Lord Peter Wimsey and Albert Campion' The Spectator December 14, at http://www.spectator.co.uk/2013/12/a-nice-gentle-murder/ (accessed 4 May 2016)

Kristeva, J 1982 Powers of horror: An essay on abjection New York: Columbia UP

Lloyd, JR 2014 'Talking to the dead - the voice of the victim in crime fiction' New Writing: The International Journal for the Practice \& Theory of Creative Writing, 11 (1), 100-108

Lucas, R 2004 'Anxiety and its antidotes: Patricia Cornwell and the forensic body' Literature Interpretation Theory, 15 (2), 207-222

Lynch, T 2006 'Mourning in America' The New York Times February 26, at http://www.nytimes.com/2006/02/26/books/review/26lynch.html?fta=y\&_r=0 (accessed 28 April 2016)

Messud, C 2009 'Death in literature' Newsweek 3 June 2009, at http://www.newsweek.com/deathliterature-76291 (accessed 13 September 2015)

Murta, AP 2011 'The gaze' in M Ryan (ed) The encyclopaedia of literary and cultural theory

Blackwell Reference Online, at

http://www.blackwellreference.com/public/book.html?id=g9781405183123_9781405183123 (accessed 4 May 2016)

Palmer, J 2001 'Tracing bodies: Gender, genre, and forensic detective fiction' South Central Review 18 (3/4), 54-71

Poe, EA 2003 [1846] 'The philosophy of composition' in The fall of the house of Usher and other writings D Galloway (ed) London: Penguin Classics, 430-442

Reichs, K 2011 Spider bones London: Arrow

Sayers, DL (ed) 1934 'Introduction' in Great short stories of detection, mystery and horror, third series London: Gollancz

Sebold, A 2002 The lovely bones New York: Little Brown and Company

Shillabeer, R 2014 'Death in twenty-first-century crime fiction' in M Blanco and R Vidal (eds) The power of death: Contemporary reflections on death in Western society New York: Berghahn, 102-112

Sims, A 2003 'Invited commentary on death and dying in literature' Advances in Psychiatric Treatment 9, 217-219

Skelton, J 2003 'Death and dying in literature' Advances in Psychiatric Treatment 9, 211-217

Spring, M and L King 2012 The Arvon book of crime and thriller writing London: Bloomsbury

Steenberg, L 2013 Forensic science in contemporary American popular culture: Gender, crime and science New York: Routledge

Strubel, AT 2014 'We tell ourselves stories' in O Hakola and S Kivistö (eds) Death in literature Newcastle upon Tyne: Cambridge Scholars, 3-14

Temple, P 2005 The broken shore Melbourne: Text 
'The string of pearls: A romance' 1846-7 in E Lloyd (ed) The people's periodical and family library 724

Thornton, T P 1997 'Habeas corpus: Death in nineteenth-century America' Reviews in American history 25, 433-438

Todorov, T 1977 The poetics of prose Oxford Wiley-Blackwell

Turner, B 2003 The writer's handbook: Guide to crime writing London: Macmillan

Vickroy, L 2002 Trauma and survival in contemporary fiction Charlottesville: U of Virginia P

Whitehead, A 2004 Trauma fiction Edinburgh: Edinburgh UP

Zanuck, RD (producer) Burton, T (director) 2007 Sweeney Todd: The demon barber of Fleet Street [motion picture] US: Warner Bros 